$16: 146$

<症例報告 $>$

病巣と反対側に小脳症状と感覚障害を呈した橋梗塞の 1 例

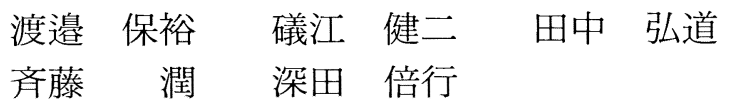

要旨：片側性の運動失調と同側の感覚障害を呈した橋梗塞の 1 症例を報告した. MRI にて症 状出現側と反対側の橋上部，底部と被蓋の境界内側に小梗塞が認められた。責任血管は，橋傍 正中枝と考えられた。対側の運動失調は主に交叉前の橋核小脳線維さらには橋被蓋網様核の障 害によると考えられた。感覚障害は内側毛帯および腹側三叉神経視床路の障害によるものと推 察した.

Key words : ataxia, sensory disturbance, lacunar infarction, pontine infarction, MRI (脳卒中16：146-150, 1994）

\section{はじめに}

今回我々は，一側性の運動失調と同側の感覚障害を 主症状とし，その責任病巣として，症状出現とは反対 側の橋上部，底部と被蓋の境界内側領域の小梗塞が疑 われた 1 症例を経験した。本症例は従来から言われて いる脳幹症候群のいずれにも当てはまらず，症候学的 に興味がある症例と考えられたので若干の考察を含め 報告する。

\section{症例}

症例 $1 ： 64$ 歳，女性.

主訴：左半身知覚異常扔よび脱力感, 後頭部頭重感。

既往歴：特記事項なし。

家族歴：父，母が脳卒中。

生活歷：飲酒，喫煙歷なし。

現病歴：1993年 6 月 6 日. 夕食途中，悪寒，動悸を 感じ頭がカーっと熱くなった。しばらくして左手のし びれ感が出現。のちに動悸，めまい感が出現した。 6 月15日当院入院となった。

入院時現症：血圧 $130 / 88 \mathrm{mmHg}$, 脈拍68/分整.

一般理学所見に異常なし.

神経学的所見: 意識清明, 右方への追視は saccadic であった。左顔面に皮をかぶったような触覚低下を認 めた。顔面筋麻痺は認めなかった。運動麻痺はなく,

島根県立中央病院神経内科

（1994年 3 月 17 日受付，1994年 5 月 7 日受理）
深部腱反射に左右差はなく正常，上下肢ともに病的反 射は認めなかった。感覚系で, 左半身の触覚過敏があっ た。痛覚, 振動覚, 関節位置覚に明らかな左右差は認 めなかった，指鼻試験，指耳試験，膝踵試験は運動測 定障害，運動の解離 (decomposition) のため左側で明 らかに拙劣であったが，閉眼による悪化は認めなかっ た。同側で変換運動障害を認めた。体幹運動失調も認 め, 歩行は不安定で開脚歩行を呈していた. Romberg 試験は陰性であった，直腸膀胱障害ほか，自律神経症 状は認めない。

入院時検查所見：検尿，末梢血に異常なし．空腹時 血糖 $94 \mathrm{mg} / \mathrm{d} l$, 総コレステロール $204 \mathrm{mg} / \mathrm{d} l$, トリグリ セライド $96 \mathrm{mg} / \mathrm{d} l$, HDL コレステロール $36 \mathrm{mg} / \mathrm{d} l$, $\beta$-thromboglobulin $41.2 \mathrm{ng} / \mathrm{m} l$ 。 心電図正常. 脳波異 常なし. SEP で右の Shagass 点で低電位, 中枢伝導時

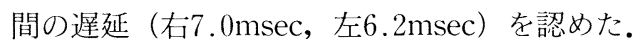

神経放射線学的検査：第10病日の頭部 CT にて，低 吸収域を認めなかった。第23病日の MRI（図 $1 a, b$, c）で，右橋上部底部内側から被蓋部に直径約 $5 \mathrm{~mm}$ の 限局性の T1強調画像で低信号を，T2強調画像で高信 号を示す病巣を認めた。

入院経過：肢節運動失調は軽度残存. 歩行可能と なった。感覚障害は，左手の触覚過敏，左踵部のしび れ感を残すのみとなり，第52病日に退院となった。

\section{考 察}

一側性運動失調と同側の感覚障害を主症状とした 1 症例を報告した。本症例は，運動失調と感覚障害がほ ぼ同時に出現し，軽快していった臨床経過とMRI 上 

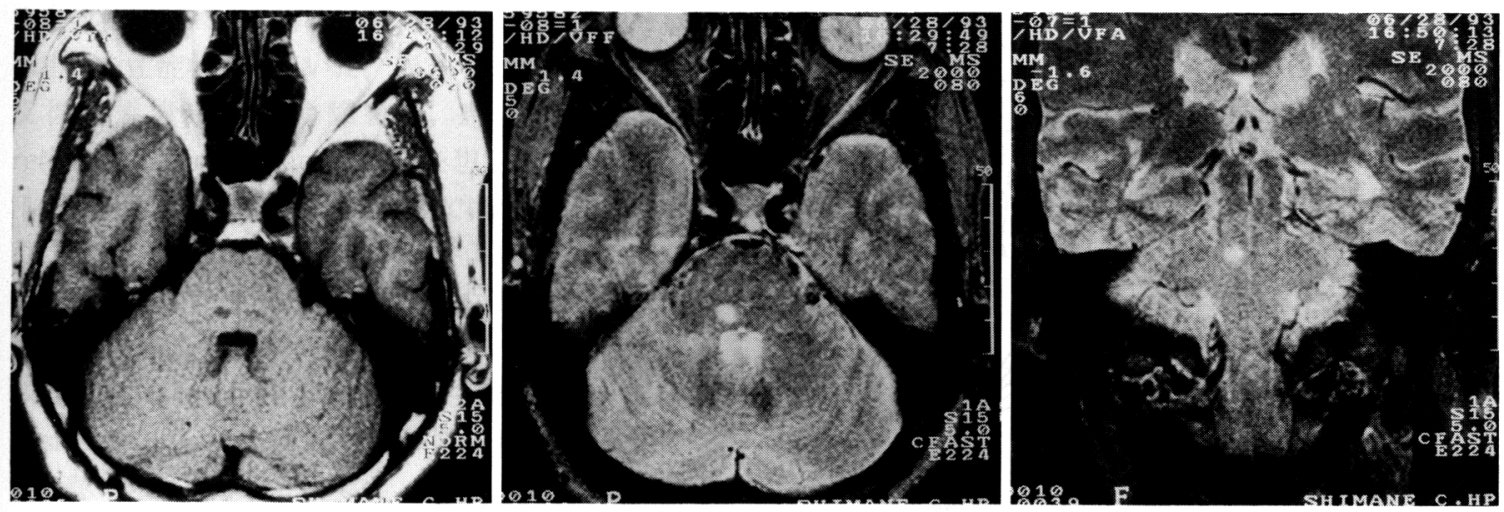

図 $1 \mathrm{a}$ ：頭部 MRI 水平断 T1WI（TR 600, TE 20). 橋底と被蓋の境界部正中よりに梗塞巣を認 める. b：頭部 MRI 水平断 T2WI (TR 2,000, TE 80). c : 頭部 MRI 冠状断 T2WI (TR 2,000, TE 80$)$. 梗塞巣は橋上部に存在する.

他に症状を説明し得る病変が確認できないことより， 症状出現とは反対側の橋上部，橋底部と被蓋の境界部 の正中に近い領域に存在した梗塞がその責任病変と考 えられた. 病変は直径約 $5 \mathrm{~mm}$ 程度の類円形病変であり 橋傍正中枝領域の lacunar infarction と考元られる1 (図 2 ).橋に㧍ける lacunar infarctionとしては, pure motor hemiparesis, ataxic hemiparesis, dysarthria clumsy hand syndromeなどが比較的よくみられる が，Fisher が記した lacunar syndrome の review ${ }^{21} に$ は本症例に該当する症候はなく, lacunar syndrome と しては例外的な症例と考えられる。

本症例の運動失調は測定障害, 協調運動障害, 変換 運動障害, 体幹運動失調, 歩行障害を主としていた. 運動失調の出現に関して深部感覚障害や前庭障害によ る運動失調の関与の可能性は全く否定はできないもの の, 閉眼による症状の悪化を認めないこと, SEP にて 内側毛帯が障害されている所見はあるものの臨床的に は深部感賞障害を認めないこと, 明らかな肢節運動失 調も存在することより小脳性の運動失調が主体となっ ていると考えられた ${ }^{3 / 4)}$.

従来, 橋の片側性病変による小脳失調は, 上小脳動 脈症候群 (Mills 症候群), 橋上部被蓋症候群, 橋中部 外側症候群, Marie-Foix cerebeller hemiparesis, 橋 中部被蓋症候群 (Grenet 症候群), 橋下部外側症候群な どいずれも病変と同側に生じる5とされており, 病変 と反対側に生じる小脳失調は, 1965年に Fisher らが提 唱した homolateral ataxia and crural paresis ${ }^{6} の ち$ の ataxic hemiparesis ${ }^{7)}$ みと言える. 責任病巣に関 しては, Mills 症候群, 橋上部被蓋症候群に関しては上
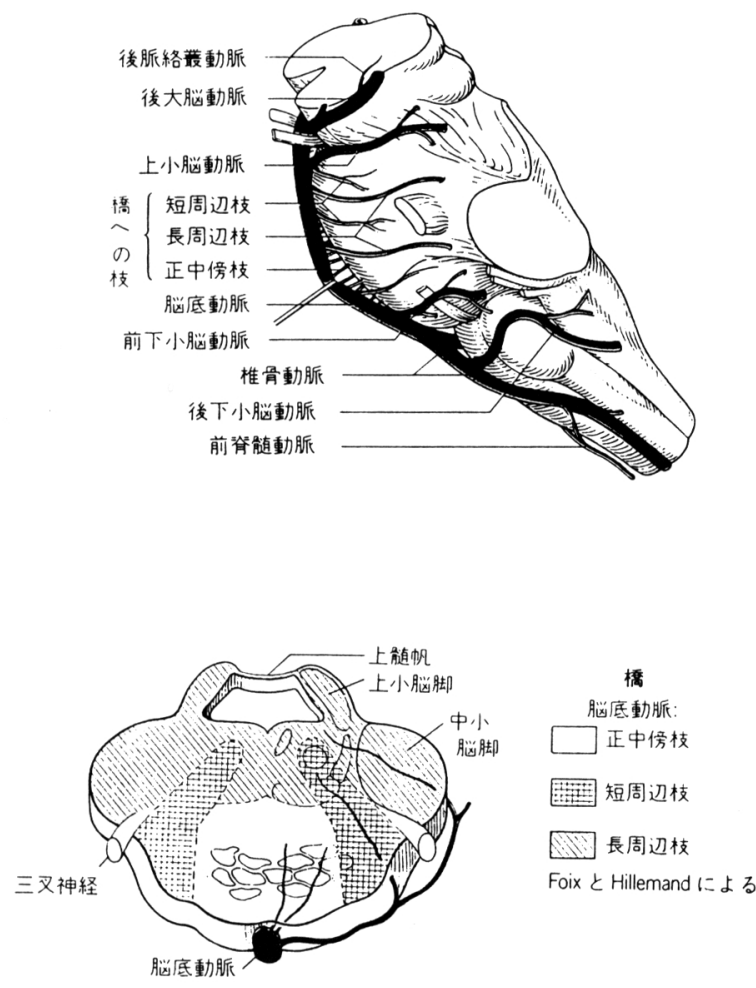

図 2 橋の血管支配. 文献1)ょり.

小脳脚が, 橋中部外側症候群, Marie-Foix cerebeller hemiparesis は中小脳脚が，橋下部外側症候群は下小 脳脚が, ataxic hemiparesis は皮質橋小脳路が原因と 考えられている.

本症例における小脳性運動失調は MRIに打ける病 巣部位より上小脳脚, 中小脳脚とは離れており,これ 


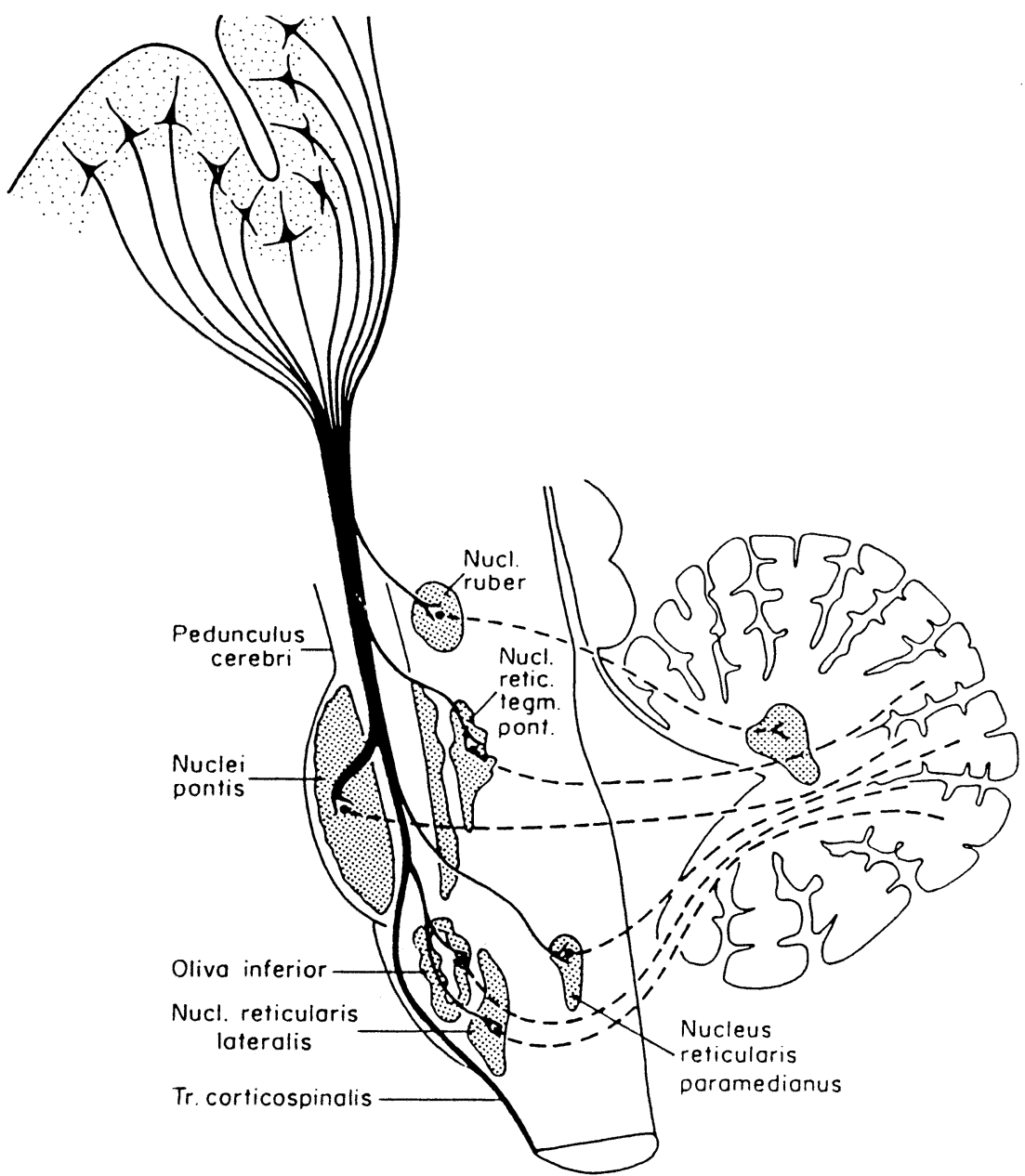

図3大脸皮質から橋核，橋被蓋網様核への線維連絡.これらの核からの 2 次ニュー ロンは大部分が対側中小脳脚を通って小脳に達する。橋被蓋網様核は上小脳脚下行 枝からの線維も受ける。文献9)より。

らの障害によって生じたとは考えにくく，皮質橋小脳 路障害により出現した可能性が考えられる. 皮質橋小 脳路は大脳皮質の殆どすべての領域からの線維を受 け, 橋核でニューロンを変え, 橋横走線維として大部 分は対側中小脳脚を通り小脳皮質の達する ${ }^{8) 9}$. 病変と 反対側の小脳症状の出現は, 交叉前の橋横走線維の障 害が関与していると考えられた。また, MRI 上, 内側 毛带を中心とした領域に梗塞巣があり, 橋被蓋網様核 (Nucleus reticularis tegmenti pontis) の障害も関与 している可能性がある.橋被蓋網様核は被蓋部腹内側 部に位置し, 橋核と同様大脳新皮質のほとんど全域か ら投射線維を受けるほか, 上小脳脚下行枝を介して小 脳核からの投射線維も受けており，対側の中小脳脚を
通り小脳へ線維を送る ${ }^{10}$ (図 3 )。橋横走線維の障害の 範囲に比し, 小脳症状は上肢, 下肢, 躬幹と広範囲に 及ぶことより, 小脳症状の出現に対し橋被蓋網様核も 重要な役割を果たしているのではないかと考えられ た. 半身の触覚過敏を主とした感覚障害は, 内側毛帯 の損傷によるものと考えられる ${ }^{111}$. 顔面における触覚 低下は求心線維二次ニューロンの腹側三叉神経視床路 における障害によると考えられた。

本症例を検討する上で興味ある 2 症例が本邦で報告 されている．1例は福井ら ${ }^{12)}$ が報告した限局性橋梗塞 により上小脳動脈症候群 (Mills 症候群) を生じた症例 で, 病巣は, 我々の症例より背内側の橋被蓋に位置す る直径約 $5 \mathrm{~mm}$ の lacunar infarction で, 病巣と同側の 
小脳症状と反対側の解離性感覚障害（選択的温 - 痛覚 障害）を主症状としていた。福井らは, 小脳症状は交 叉後の橋横走線維の障害を, 感覚障害はspinoreticulo-thalamic tractの関与を想定している.もう 1 例は, 山田ら ${ }^{13)}$ の報告した症例で, 橋被蓋傍正中部の 直径 $6 \mathrm{~mm}$ の lacunar infarctionにより, pure sensory stroke を呈した症例である. 臨床的には病巣と反対側 に触覚，深部感覚障害のみを呈している．病変と反対 側で指鼻試験, 膝踵試験がやや拙劣だったが, decompositionや dysmetria などの小脳失調を疑わせる所 見は認められなかったとして, 山田らは深部感覚障害 によるものと考察している. 我々の症例, 福井らの症 例および山田らの症例は, いずれも MRI 上の梗塞部 位は非常に近接しているものの, 呈した症候は異なり かつ紛らわしい. MRI の導入により, 従来の CT scan では検出できないような小梗塞, 特に後頭蓋窩の病変 の検出率が飛躍的に向上した，それに伴い生前に臨床 症状と病変部位との対応を検討することも容易とな り, 従来から言われている脳幹症候群の典型的症候を 呈する症例はむしろ例外的だとの報告がある ${ }^{14)}$. 橋梗 塞における運動失調の出現側および出現機序, 感覚障 害の種類についてさらに検討が必要であると考えられ た.

\section{結語}

橋上部, 底被蓋境界内側の小梗塞で, 病変と反対側 に小脳症状と感覚障害を呈した 1 症例を報告した。 予 後は比較的は良好で, 退院時には歩行可能となった。 小脳症状と同側の感覚障害を呈する場合, 視床の障害 がまず考えられるが，橋における病変も同様な症状を 呈する可能性があると考えられた。

ご校閲をいただいた恩師，高橋和郎先生に深謝いたしま す.

\section{文献}

1）半田 肇監訳：神経局在診断一その解剖, 生理, 臨床一. 第 3 版, 文光堂, 東京, $1988, \mathrm{pp} 176-179$

2) Fisher $\mathrm{CM}$ : Lacunar strokes and infarcts: $\mathrm{A}$ review. Neurology $32: 871-876,1982$

3）平山恵造：神経症侯学. 文光堂, 東京, 1971, pp1039 $-1045$

4）平山恵造：小脳症状一臨床的分析と病変部位一. 神経進歩 17:986-996, 1973

5）平井俊策：局在診断のための脳幹症侯群。神経内 科 $2: 503-510,1975$

6) Fisher CM, Monroe C: Lacunes: Homolateral ataxia and crural paresis: A vascular syndrome. J Neurol Neurosurg Psychiat 28: 48 $-55,1965$

7) Fisher $\mathrm{CM}$ : Ataxic hemiparesis: A pathologic study. Arch Neurol 35 : 126-128, 1978

8）水野昇, 岩堀修明: 図説 中枢神経系第 2 版. 医学書院, 東京, 1991, pp205-218

9) Brodal A: Cerebrocerebellar pathways. Anatomical data and some functional implications. Acta Neurol Scand 48: 153-195, 1972

10) Brodal A: Neurological anatomy, in relation to clinical medicine 3rd ed. Oxford University Press, New York, 1981, pp46-147

11）福井俊哉, 鈴木義夫, 佐藤 温ら：限局性橋梗塞に よる上小脳動脈症侯群 (Mills 症侯群) の 1 例一 $\mathrm{X}$ 線 CT scan, MRI, SPECT による文献的対比検討 一. 神経内科 $35: 416-423,1991$

12）山田淳夫, 北条和佳子, 佐々木石雄ら：Pure sensory stroke を呈した橋ラクーネ梗塞の 1 例. 脳神 経 45: 1151-1153, 1993

13）水野 昇: 脊髄を上行する感覚神経路の解剖. 脳 神経 42:1125-1140, 1990

14）田崎義昭：脳幹梗塞の臨床．臨床神経 30：1291 $-1300,1990$ 


\title{
Abstract \\ A case of pontine infarction showing hemiataxia with homolateral sensory disturbance
}

\author{
Yasuhiro Watanabe, M.D., Kenji Isoe, M.D., Hiromichi Tanaka, M.D., \\ Jun Saitou, M.D. and Masuyuki Fukada, M.D. \\ Department of Neurology, Shimane Prefectural Central Hospital
}

We report a female case of pontine lacunar infarction showing hemiataxia and homolateral sensory disturbance. The ataxia consisted of limb ataxia and truncal ataxia on the left side. The sensory disturbance appeared as paresthesia on the left half of the body and hypesthesia on the left half of the face. MRI revealed a small lacunar infarction at an opposite site in the upper pons. The lesion was situated in the border zone between the base and tegmentum, and almost on the midline. It was thought to be an infarction in the territory of the paramedian artery. Contralateral cerebellar signs were thought to have been caused by interruption of the precrossed pontocerebellar fibers or destruction of the reticular tegmental pontine nucleus. Further, destruction of the medial lemniscus and ventral trigeminothalamic tract was thought to have elicited sensory disturbance.

(Jpn J Stroke 16: 146-150, 1994) 